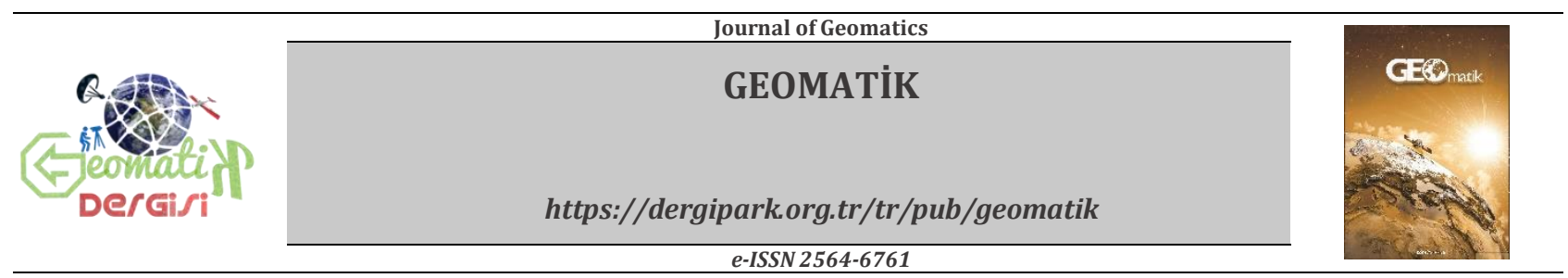

\title{
Thornthwaite iklim sınıflandırma yöntemine göre Karadeniz Bölgesi iklim sınır haritasının CBS ile üretilmesi
}

\author{
Hüsniye Ebru Çolak¹, Tuğba Memişoğlu*1 \\ ${ }^{1}$ Karadeniz Teknik Üniversitesi, Mühendislik Fakültesi, Harita Mühendisliği Bölümü, Trabzon, Türkiye
}

\author{
Anahtar Kelimeler \\ İklim sınır haritası \\ Thornthwaite iklim sinıflama \\ yöntemi \\ CBS \\ Kriging enterpolasyon yöntemi \\ Karadeniz Bölgesi
}

\begin{abstract}
ÖZ
İklim karakterlerinin bilinmesi, farklı iklim tiplerine sahip sınırların tespitine olanak sağlamakta; bu durum bölge kaynaklarının sürdürülebilir kullanımının sağlanması ve arazi kullanım planlarına yön verilmesi açısından önem arz etmektedir. İklimsel sınırların tespiti ayrıca iklimin mülkiyet üzerindeki etkilerinin belirlenerek önlenebilmesine ve mülkiyet üzerindeki kullanımın daha planlı ve kontrollü çerçevede ele alınmasına altlık oluşturabilmektedir. Bu bağlamda iklimsel sınırların tespiti noktasında iklim sınıflama yöntemleri geliştirilmiştir. Bu yöntemler, iklim tiplerinin bölgesel farklılığının tespit edilmesi, yıllara bağlı olarak değișiminin incelenmesi ve iklim tiplerine uygun olacak șekilde farklı sınırların olușturulmasına imkân sağlamaktadır. Bu çalıșmada iklimin mülkiyet kullanımında etkili rol oynaması ve dolayısıyla da planlama noktasında altlık oluşturacak olması gereksinimlerinden yola çıkarak, Karadeniz Bölgesi (Artvin, Ordu, Rize, Rize-Pazar, Trabzon, Şebinkarahisar, Akçaabat, Ünye, Bafra, Hopa, Giresun ve Samsun'da yer alan meteorolojik istasyon noktaları) iklim sınır haritasının olușturulması esas alınmıștır. Bölgeye ait meteorolojik istasyon noktalarında 1988-2018 yılları arasında ölçümü yapılmıș son 30 yıllık hava durumu parametreleri temin edilerek, konumla ilișkilendirilmiș ve Coğrafi Bilgi Sisteminde (CBS) bir veritabanında düzenlenmiștir. Ardından meteorolojik veriler Thornthwaite iklim sınıflaması yöntemine göre değerlendirilerek meteorolojik istasyon noktalarının iklim tipleri sınıflandırılmıștır. Son olarak iklim tipi belirlenmiş meteorolojik noktalar esas alınarak, Kriging enterpolasyon yöntemi ile tüm bölgeyi yansıtan iklim sınır haritaları üretilmiștir. Elde edilen sonuç ürünün bașta iklim sınırlarını yansıtması, ayrıca mülkiyetin iklim yönünden kullanım vasfının etkilendiği ve değișim gösterdiği alanların tespit edilmesi; böylece yapılacak planlama ve koruma odaklı mülkiyet çalıșmalarına altlık oluşturması hedeflenmektedir. Ayrıca bu çalışma ile Meteoroloji Genel Müdürlüğünün (MGM, 2017) iklim sınıflandırması konusunda gerçekleștirdiği çalışmasına, ilçe sınırlarından bağımsız raster tabanlı grid ağ şeklinde iklim sınırlarının elde edilmesi yönüyle farklı açıdan yaklaşılacağından MGM'nin ilerki çalışmalarına önemli katkılar sağlayacağı düșünülmektedir.
\end{abstract}

\section{Production climate border maps with GIS of Black Sea Region of Turkey according to Thornthwaite climate classification method}

\author{
Keywords \\ Climate boundary map \\ Thornthwaite climate \\ classification method \\ GIS \\ Kriging interpolation method \\ Black Sea Region
}

\begin{abstract}
To know the climate characteristics allows the determination of borders with different climate types; this is important in terms of ensuring the sustainable use of regional resources and direction of land use plans. The determination of climatic boundaries may also serve as a basis for determining and preventing the effects of climate on property and addressing the use of property on a more planned and controlled framework. In this context, climatic classification methods have been developed to determine climatic boundaries. These methods allow the determination of the regional differences of climate types, the examination of the changes over the years and the establishment of different boundaries to suit the climate types. In this study,
\end{abstract}


requirements that an effective role of climate in property use and establish a foundation at the planning point, the formation of the climate border map of the Black Sea Region (meteorological stations in Artvin, Ordu, Rize, Rize-Pazar, Trabzon, Sebinkarahisar, Akcaabat, Unye, Bafra, Hopa, Giresun and Samsun) was taken as basis. The last 30 years of weather parameters measured at the meteorological station points of the region between 1988 and 2018 were obtained, related to the location and arranged in a database in the Geographical Information System (GIS). Then, meteorological data were evaluated according to Thornthwaite climate classification method and climatic types of meteorological station points were classified. Finally, meteorological points with climate type were subjected to Kriging interpolation method and climate boundary maps reflecting the whole region were produced. The resultant product will reflect the climatic boundaries, and the areas where the property's use in terms of climate will be affected and changed; thus, it will serve as a basis for planning and conservationoriented property works. In addition, this study will make significant contributions to the future studies of the General Directorate of Meteorology (MGM, 2017) as it is approached from different perspectives in terms of obtaining climate boundaries in the form of raster-based grid network independent of district boundaries.

\section{GİRiş}

\subsection{Problemin Tanımı}

Coğrafya üzerinde iklim değişikliğinden kaynaklı iklim karakterlerinin bilinmesi oldukça önemlidir (IPCC 2014). İklim karakterlerinin bilinmesi, farklı iklim tiplerine sahip sınırların tespit edilmesine olanak sağlarken; bölge kaynaklarının sürdürülebilir kullanımının devam ettirilebilmesi, arazi kullanım planlarının ve mülkiyet üzerindeki kullanımın daha planlı ve kontrollü çerçevede etkin bir şekilde ele alınmasına önemli ölçüde katkıda bulunmaktadır.

Günümüzde iklimsel karakterlerin tanımlanarak dikkate alınması gerekliliği Türkiye İklim Stratejisi 2013-2023 vizyonunda belirtilen “Ulusal İklim Değişikliği Stratejisi'nde ele alınmıştır (TIDS 2010). Bu vizyonda iklimden kaynaklı sorunların tespit edilerek stratejiler geliştirilmesi ve iklim değişikliğinin izlenmesinin gerekliliği vurgulanmaktadır. Bu stratejinin yanında özellikle mülkiyet kullanımının sürdürülebilir bir şekilde devam ettirilebilmesine önemli ölçüde vurgu yapan Uluslararası Haritacılar Federasyonu (FIG) tarafından 1998 yılında yayınlanan, geleceğin kadastrosu ile de ilgili öngörüleri bünyesinde barındıran Kadastro 2014 vizyon çalışması sonuç bildirgesi raporunda, iklimsel değişikliklerin insan ırkına ve mülkiyet haklarına olan yararının belirlenmesi ve irdelenmesi gerekliliği üzerinde önemle durulmuştur (FIG 2014; Kaufmann and Steudler 1998).

İklim karakterleri tespiti, iklim sinıflarının tanımlanmasıyla gerçekleştirilmektedir. İklim sınıflandırma, iklim tiplerini ayrt etmek, iklim açısından birbiriyle benzeyen ya da benzemeyen alanları belirleyerek iklim sınırlarının çizilmesini sağlamaktadır (MGM 2017). İklim konusunda çalıșan birçok bilim adamı yürüttükleri çalışmalar doğrultusunda çok sayıda iklim sınıflama yöntemi ortaya çıkarmış ve kullanmıştır. Bu yöntemler ilk olarak Köppen (1918) tarafından yapılan sınıflandırmalar ile ortaya çıkmış daha sonra farklı bilim insanları tarafından geliştirilmiştir (Köppen 1918). Farklı iklim sınıflama yöntemlerinin mevcut olması, genellikle kullanılan algoritmaların farklılık arz etmesinden ileri gelmektedir. Dolayısıyla aynı bölgeyi farklı iklim tipleriyle ifade etmek mümkün olmaktadır. Bu yöntemlerden bazıları; Köppen (1918), Thornthwaite (1948), Trewartha (1968), Aydeniz (Aydeniz 1985), Erinç (1949), De Martonne (1942), Köppen-Geiger (1954) yöntemleri şeklindedir. $\mathrm{Bu}$ yöntemler kullanılarak gerek bölgesel gerekse lokal bazlı iklim sınıflandırma çalışmaları yürütülebilmektedir. Bugüne kadar hem akademik araştırmalarda hem de uluslararası alanda doğan gereksinimler doğrultusunda, iklim sınıflamasının farklı yöntemler kullanılarak yapılması ve bölgesel karşılaştırmalarla iklim etkilerinin incelenmesi üzerine çalışmalar gerçekleștirilmiștir. $\mathrm{Bu}$ çalıșmalardan bazıları iklimsel farklılıkları (Fovell and Fovell 1993; Çiçek 1996; Tayanç ve Toros 1997; Tayanç vd. 1997; Demircan ve Şensoy 2010; Apaydın vd. 2011; Bayramoğlu 2013; Birdal vd. 2018 ve sıcaklığın diğer etkenler üzerindeki etkilerini ele alırken (Khorrami vd. 2019; Nacef vd. 2016), bazıları ise iklim sınıflama yöntemlerini kullanarak analizler gerçekleştirmiştir (Birsoy ve Ölgen 1992, Verep vd. 2002, Wang and Overland 2004, Akın vd. 2011, Chen and Chen 2013, Feddema 2013, Kafalı ve Yılmaz 2013, Belda et al. 2014, Yılmaz ve Çiçek 2016, Rolim et al. 2016, Aparecido vd. 2016; Yılmaz ve Çiçek 2018; Acheson vd. 2019; Zeroual vd. 2019, Rahimi vd., 2019).

Diğer bir yandan ülkemizde Meteoroloji Genel Müdürlüğü 1981-2010 yılları arasındaki 30 yıllık verilerini kullanarak, iklim sınıflama yöntemlerine göre iklim sınırları haritasını Türkiye il geneli için üretmiştir ve 2016 yılında raporlayarak kurumun internet sayfası üzerinden sunmuştur (MGM 2016; MGM 2017). Ancak bu çalıșmalar 2010 yılına kadarki son 30 yıllık verilerden üretilmiş statik yapıdaki haritalardır; yani yöntemler kullanılarak bir defaya mahsus olacak şekilde üretilmiş ve rapor şeklinde sunulmuştur. Ayrıca, bu yöntemler kullanılarak elde 
edilen sonuç haritaların istasyon bazlı elde edilip ilçe sınırlarına bağlı kalınarak genelleştirilmesi önemli bir sorun teşkil etmektedir. Çünkü iklim sınırları, birebir ilçe sınırlarıyla örtüşen sınırları temsil etmemekte; dolayısıyla iklim sınırların coğrafya üzerinde tam anlamıyla belirlenmesi gerekmektedir. Tüm bu ihtiyaçlar, çalışmanın gerçekleştirilmesinde dikkate alınan önemli çıkış noktalarıdır.

\section{2. Çalışmanın Amacı}

$\mathrm{Bu}$ çalıșmada gerek ülkenin iklim üzerine öngördüğü stratejisi gerek mülkiyet bağlamındaki öngörüsü gerekse de ilçe bazlı iklim sınırlarını yansitan haritalar üretilmesi gibi gereksinimlerden yola çlkarak iklim sınırlarının tespiti gerçekleştirilmiştir. Bu bağlamda pilot bölge olarak seçilen illere ait meteorolojik istasyon verileri, 19882018 yıllarını kapsayacak şekilde Meteoroloji Genel Müdürlügü̈nden temin edilmiş, elde edilen veriler düzenlenerek ve konumla ilişkisi sağlanarak Thornthwaite iklim sınıflaması yöntemine göre iklim tipleri belirlenmiştir. Son olarak iklim tipleri belirlenen istasyon noktalarından yararlanılarak, Kriging enterpolasyon yöntemi uygulanmıştır ve CBS tabanlı tüm bölgeyi yansıtan iklim sınırları yüzey haritası üretilmiştir.

\section{YÖNTEM}

\section{1. Çalışma Alanı}

$\mathrm{Bu}$ çalışmanın ilk aşaması olarak pilot bölge seçimi yapılmıştır. Bu bağlamda, Karadeniz Bölgesinde yer alan Artvin, Ordu, Rize, Rize-Pazar, Trabzon, Şebinkarahisar, Akçaabat, Ünye, Bafra, Hopa, Giresun ve Samsun'daki istasyon noktalarını barındıran bölge çalışma alanı olarak seçilmiştir. Bunun sebebi, özellikle 30 ylllı süreçte ölçüm alınmış istasyon verilerini kapsayan bölgelerin seçilmesi öncelikli olmuştur. Çalışma bölgesi kıyı ile iç kesim arasında farklılığın en fazla olduğu alanları ve ayrıca ülkenin en fazla yağış alan bölümünü bünyesinde barındırmaktadır.

Çalışma alanı Şekil 1'de görülmektedir.

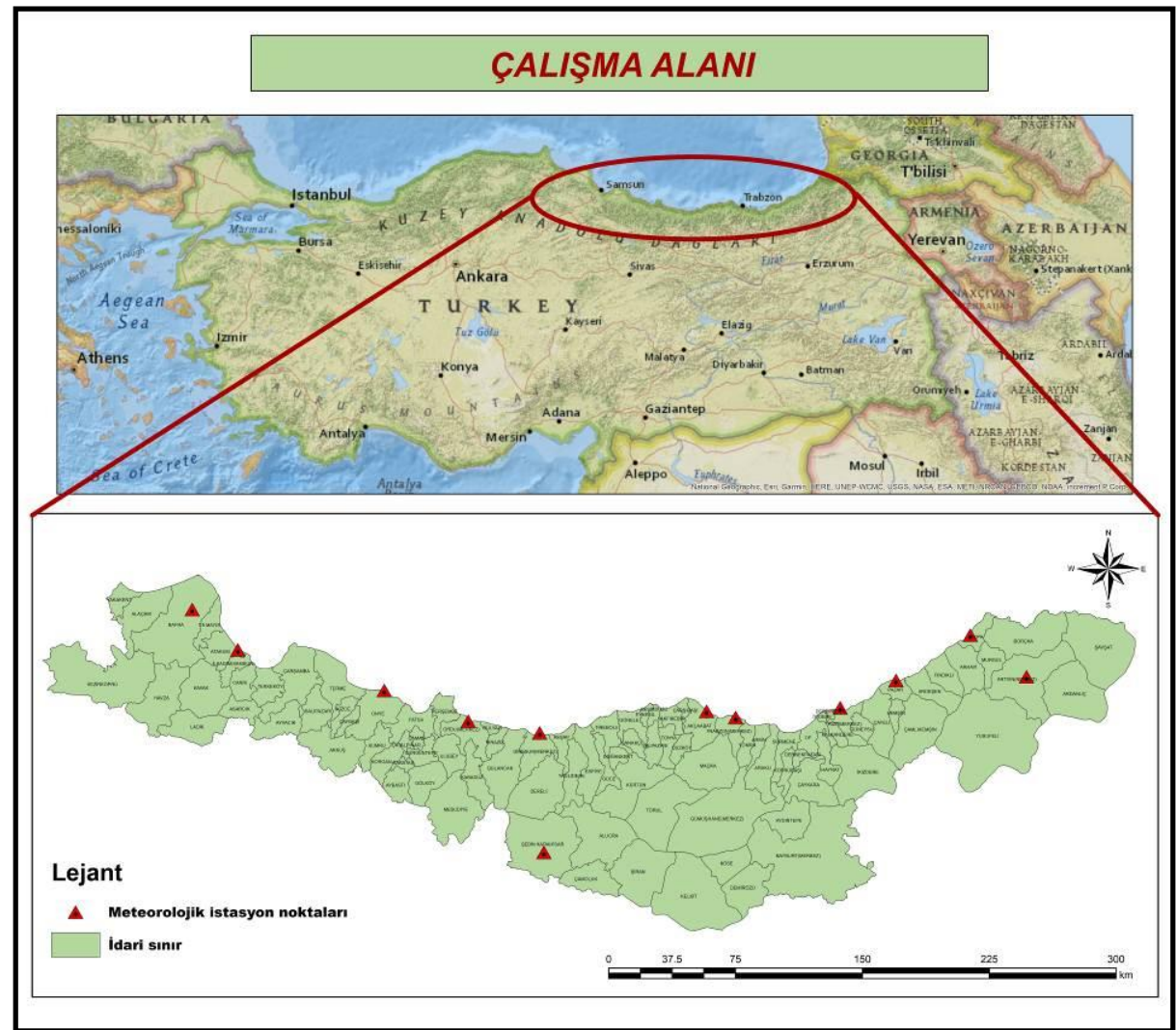

Şekil 1. Çalışma alanı

\subsection{Thornthwaite iklim sınıflandırması yöntemi}

Çalışmanın ikinci aşamasında iklim sınırlarının tespiti noktasında kullanılması gereken yöntem seçilmiştir. Bu çalışma için yöntem olarak Thornthwaite iklim sınıflandırma yöntemi esas alınmıștır. Thornthwaite iklim sınıflandırması yöntemi, Amerikalı iklim bilimci C. Warren Thornthwaite tarafindan ortaya çıarilan ve Potansiyel Evapotranspirasyon (ETP) kavramına dayanan bir yöntemdir (Thornthwaite 1948). Potansiyel evapotranspirasyon kavramı, sıcaklığın artmasiyla birlikte artan ve nemin artmasiyla birlikte azalan teorik bir değerdir.

Potansiyel evapotranspirasyon aşağıdaki formüller kullanılarak tespit edilir (Thornthwaite 1948). Bu formülde (t) aylık ortalama sıcaklık, (I) yıllık sıcaklık indeksi, (G) ise enlem düzeltme katsayısını ifade etmektedir. 


$$
\begin{aligned}
& I=\sum_{1}^{12} i \\
& i=\left(\frac{t}{5}\right)^{1.514}
\end{aligned}
$$$$
E T P=16 *\left(\frac{10 * t}{I}\right)^{a} * G
$$$$
a=6.7510 * 10^{-7} * I^{3}-7,7110 * 10^{-5} * I^{2}
$$$$
+1,791210 * 10^{-2} * I+0,49239
$$

Thornthwaite iklim sınıflandırma yönteminde, iklim sınıflaması yapılabilmesi için öncelikle su bilançosu tablosu oluşturulmak zorundadır. Bu tablo, aylık ortalama yağıș, ortalama sıcaklık ve evapotranspirasyon değerleri kullanılarak oluşturulur ve bu değerlere bağlı olarak gerçek potansiyel evapotranspirasyon, su fazlası, su noksanı, akış, nemlilik gibi değerler elde edilir (Thornthwaite 1948).

Oluşturulan su bilançosu tablosundaki değerlerden potansiyel evapotranspirasyon, su fazlası ve su noksanı kullanılarak, iklim tiplerini yansıtan harflerin belirlenmesi için yağış etkinlik indeksi, sıcaklık etkinlik indeksi, yağış rejim indeksi ve ETP'nin üç yaz oranına olan indeksi hesabı gerçekleştirilir. Her bir işlem adımı iklim tipinin bir harfini temsil etmektedir. Toplamda Thornthwaite iklim sınıflandırması dört ișlem adımında gerçekleştirilir (Thornthwaite 1948):

Thornthwaite iklim sınıflandırması yönteminin ilk aşaması, yağıș etkinlik indeksinin hesap edilmesidir. $\mathrm{Bu}$ indeks değeri, kurak iklimler ve nemli iklimler şeklinde iki büyük grupta toplanmıştır, sonuçta en nemliden en kurağa doğru sıralayarak sınıflanmıştır. Thornthwaite iklim sınıflandırmasında birinci harf, yağış etkinlik indeksi değeridir ve (Im) formülü kullanılarak elde edilir (Thornthwaite 1948) (Tablo 1). Bu formülde (s) yıllık su fazlasını, (d) yıllık su noksanını ifade etmektedir.

$$
\operatorname{Im}=(100 * s-60 * d) / \text { ETP }
$$

Tablo 1. Thornthwaite yağış etkinlik indeksi ve iklim özelliği

\begin{tabular}{clc}
\hline Im & Harf & İklim özelliği \\
\hline $\mathbf{> 1 0 0}$ & A & Cok nemli \\
\hline $\mathbf{1 0 0 - 8 0}$ & B 4 & Nemli \\
\hline $\mathbf{8 0 - 6 0}$ & B & Nemli \\
\hline $\mathbf{6 0 - 4 0}$ & B2 & Nemli \\
\hline $\mathbf{4 0 - 2 0}$ & B1 & Nemli \\
\hline $\mathbf{2 0 - 0}$ & C2 & Yarı Nemli \\
\hline $\mathbf{0 - ( - 2 0 )}$ & C1 & Yarı Kurak-Az Nemli \\
\hline $\mathbf{- 2 0 - ( - 4 0 )}$ & D & Yarı Kurak \\
\hline $\mathbf{- 4 0 - ( - 6 0 )}$ & E & Tam Kurak-Çöl \\
\hline
\end{tabular}

Thornthwaite iklim sınıflandırmasındaki ikinci harf, Thornthwaite sicaklık etkinlik indeksini oluşturur. $\mathrm{Bu}$ değer, Yıllık ETP değerleri esas alınarak tespit edilir (Thornthwaite 1948) (Tablo 2).
Tablo 2. Thornthwaite sıcaklık etkinlik indeksi ve iklim özelliği

\begin{tabular}{lcl}
\hline Yıllık ETP (mm) & Harf & Íklim Özelliği \\
\hline 1141 ve fazlası & A' $^{\prime}$ & Megatermal \\
\hline $998-1140$ & B'4 $^{\prime}$ & 4.Derece Mezotermal \\
\hline $856-997$ & B'3 $^{\prime}$ & 3.Derece Mezotermal \\
\hline $713-855$ & B'2 $^{\prime}$ & 2.Derece Mezotermal \\
\hline $571-712$ & B'1 $^{\prime}$ & 2.Derece Mezotermal \\
\hline $428-570$ & C'2 $^{\prime}$ & 2.Derece Mikrotermal \\
\hline $286-427$ & C'1 $^{\prime}$ & 1.Derece Mikrotermal \\
\hline $143-285$ & D' $^{\prime}$ & Tundra \\
\hline 142 ve daha az & E' $^{\prime}$ & Don \\
\hline
\end{tabular}

Thornthwaite sınıflandırmasındaki üçüncü harf, yağış rejimi indekslerini oluşturur. Bu sınıflandırmada, yıllık ETP değeri, su fazlası ve su eksiği kullanılır. Yağış rejimi indeksleri yağışlı iklimler için kuraklık indeksi (Ia), kurak iklimler için nemlilik indeksi (Ih) olarak iki şekildedir. Yağışlı iklimler için kuraklık indeksi için (5), kurak iklimler için nemlilik indeksi ise (6) formülleri hesap edilerek iklim özellikleri belirlenir (Tablo 3-4) (Thornthwaite 1948).

$$
\begin{aligned}
& \mathrm{Ia}=(100 * \mathrm{~d}) / \mathrm{ETP} \\
& \mathrm{Ih}=\left(100^{*} \mathrm{~s}\right) / \mathrm{ETP}
\end{aligned}
$$

\begin{tabular}{|c|c|c|}
\hline $\begin{array}{l}\text { Kuraklık } \\
\text { İndeksi (Ia) }\end{array}$ & Sembol & İklim Özelliği \\
\hline $0-16,7$ & $\mathrm{r}$ & $\begin{array}{l}\text { Su noksanı olmayan veya } \\
\text { pek az olan }\end{array}$ \\
\hline $16,8-33,3$ & s & $\begin{array}{l}\text { Su noksanı yaz } \\
\text { mevsiminde ve orta } \\
\text { derecede olan }\end{array}$ \\
\hline $16,8-33,3$ & $\mathrm{w}$ & $\begin{array}{l}\text { Su noksanı kış } \\
\text { mevsiminde ve orta } \\
\text { derecede olan }\end{array}$ \\
\hline 33,4 ve fazlası & s2 & $\begin{array}{lll}\text { Su noksanı } & \text { yaz } \\
\text { mevsiminde ve çok } \\
\text { kuvvetli olan }\end{array}$ \\
\hline 33,4 ve fazlası & w2 & $\begin{array}{l}\text { Su noksanı kış } \\
\text { mevsiminde ve çok } \\
\text { kuvvetli olan }\end{array}$ \\
\hline
\end{tabular}

Tablo 3. Thornthwaite kuraklık indeksi ve iklim özelliği

Tablo 4. Thornthwaite nemlilik indeksi ve iklim özelliği

\begin{tabular}{lcl}
\hline $\begin{array}{l}\text { Nemlilik } \\
\text { Indeksi (Ih) }\end{array}$ & Sembol & İklim Özelliği \\
\hline $0-10$ & $\mathrm{r}$ & $\begin{array}{l}\text { Su fazlası olmayan } \\
\text { veya pek az olan }\end{array}$ \\
\hline $11-20$ & $\mathrm{~s}$ & $\begin{array}{l}\text { Su fazlası kış } \\
\text { mevsiminde ve orta } \\
\text { derecede olan }\end{array}$ \\
\hline $11-20$ & $\mathrm{w}$ & $\begin{array}{l}\text { Su fazlası yaz } \\
\text { mevsiminde ve orta } \\
\text { derecede olan }\end{array}$ \\
\hline 21 ve fazlası & $\mathrm{s} 2$ & $\begin{array}{l}\text { Su fazlası kış } \\
\text { mevsiminde ve çok } \\
\text { kuvvetli olan }\end{array}$ \\
\hline 21 ve fazlası & w2 & $\begin{array}{l}\text { Su fazlası yaz } \\
\text { mevsiminde ve çok } \\
\text { kuvvetli olan }\end{array}$ \\
\hline
\end{tabular}


Thornthwaite sınıflandırmasındaki iklim tiplerinin dördüncü harfi ise yaz aylardaki Potansiyel Evapotranspirasyonun, ylllı Potansiyel Evapotranspirasyona oranlanarak tespit edilmesidir. Buradaki üç yaz ayı haziran, temmuz, ağustos aylarına ait yıllık sıcaklık oranların ifade etmektedir (Thornthwaite 1948) (Tablo 5).

Sonuçta, bu dört işlem adımı birleştirilerek meteorolojik istasyon noktasına dair Thornthwaite iklim sınıflaması tespit edilmiş olur.

Tablo 5. Thornthwaite ETP'nin üç yaz ayına oranı indeksi ETP'nin 3 yaz ayına oranı

\begin{tabular}{ll}
\hline ETP'nin 3 yaz ayına oranı & Harf \\
\hline 48 ve daha az & $\mathrm{a}^{\prime}$ \\
\hline $48,1-51,9$ & $\mathrm{~b}^{\prime} 4$ \\
\hline $52,0-56,3$ & $\mathrm{~b}^{\prime} 3$ \\
\hline $56,4-61,6$ & $\mathrm{~b}^{\prime} 2$ \\
\hline $61,7-68,0$ & $\mathrm{~b}^{\prime} 1$ \\
\hline $68,1-76,3$ & $\mathrm{c}^{\prime} 2$ \\
\hline $76,4-88,0$ & $\mathrm{c}^{\prime} 1$ \\
\hline 88,1 ve daha fazla & $\mathrm{d}^{\prime}$ \\
\hline
\end{tabular}

\subsection{Kriging Enterpolasyon Yöntemi}

Yeni noktaların değerlerinin, bilinen yakın noktaların değerlerinin ağırlıklı ortalaması alınarak tahmin edilmesine yarayan yöntemdir (Yaprak ve Arslan 2008; Uyan 2019). Kriging enterpolayon yöntemi, her bir tahmin edilecek nokta için bir varyans değeri hesabı yaparak değeri bilinmeyen noktaların değerini tayin eder. Bu şekilde tahmin edilen değerin güven derecesinin varyans ile ölçümü sağlanması nedeniyle diğer enterpolasyon yöntemlerinden ayrılır. Kriging yönteminin uygulanmasında şu formül kullanılır; (Yaprak ve Arslan 2008; Çolak, 2010; Akar 2017).

$$
N_{p}=\sum_{i=1}^{n} P_{i} \times N_{i}
$$

$\mathrm{Bu}$ formülde $\mathrm{n}$ nokta sayısı, Ni NP in hesap edilmesinde kullanılan geoit ondülasyonu, NP
Aranılan ondülasyon değeri, Pi N'nin hesabında kullanılan her Ni değerine karşıllı gelen ağırlık değerini göstermektedir.

Kriging enterpolasyon yöntemi diğer enterpolasyon tekniklerine nazaran daha tarafsız sonuçlar elde eder; en düşük varyans değeri ve gerçekleștirilen tahmine ait standart sapma hesaplaması ile de kestirimin doğruluğunu araştırır (Yaprak ve Arslan 2008).

$\mathrm{Bu}$ çalışmada Kriging enterpolasyon yöntemi, çalışma bölgesi içerisinde iklim tipi belirlenmiş meteorolojik istasyon noktalarından bütüncül iklim sınır haritasının elde edilmesinde kullanılmıștır. Öncelikle Thornthwaite iklim sınıflandırması ile istasyon noktalarında iklim tipleri belirlenmiş ve ardından bu örneklem noktaları esas alınarak diğer bilinmeyen noktalardaki iklim tiplerinin kestirimi kriging enterpolasyon yöntemi analiz kullanılarak elde edilmiş ve Karadeniz Bölgesi'ne ait iklim sınır haritası üretilmiştir.

\subsection{Uygulama için Verilerin Temini ve Coğrafi Veri Tabanının (CVT) Oluşturulması}

Çalışmanın üçüncü aşamasında, çalışma bölgesine ait yaklaşık 30 yıllık iklim verilerinin kaydedildiği istasyon noktalarının hangileri olduğu belirlenmiştir. Bu çalışma kapsamında Karadeniz Bölgesi illerinden Artvin, Ordu, Rize, Rize-Pazar, Trabzon, Şebinkarahisar, Akçaabat, Ünye, Bafra, Hopa, Giresun ve Samsun'da yer alan meteorolojik istasyon noktaları seçilmiş olup, bunlar toplamda 12 adettir.

Çalışmada kullanılacak veriler Meteoroloji Genel Müdürlüğü'nden kurum yazıları ile Excel formatlı olarak temin edilmiştir. Elde edilen veriler konumla ilişkilendirmek üzere her bir istasyon noktası için ayrı ayrı düzenlenmiştir. Daha sonra her bir ilin konum bilgileri ile MGM'den alınarak düzenlenmiş excel formatlı veriler ilişkilendirilerek coğrafi veritabanına aktarılmıș ve analize hazır hale getirilmiştir.

Çalışmanın iş akış şeması Şekil 2'de gösterilmektedir.

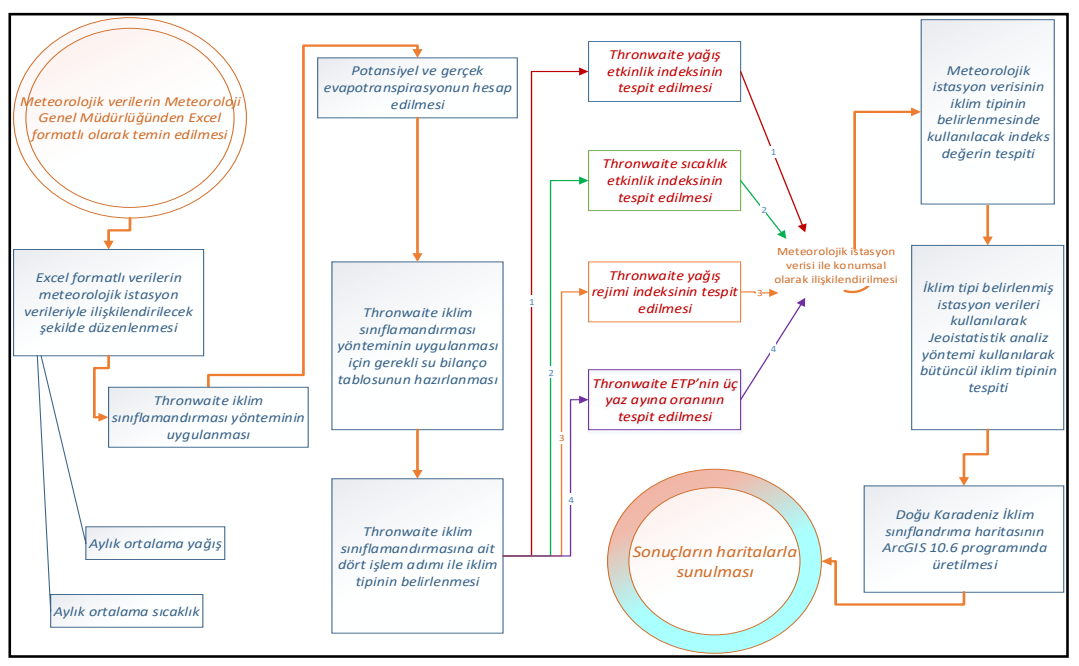

Şekil 2. Çalışmanın iş akış şeması 


\section{BULGULAR}

\subsection{Doğu Karadeniz Bölgesi İllerine Ait Meteorolojik Verilere Dayalı Su Bilanço Tablosunun Oluşturulması}

Çalışmanın bu aşamasında CVT'de düzenlenen veritabanındaki veriler kullanılarak Thornthwaite iklim sınıflaması su bilançosu tablosu hazırlanmıștır. Tabloya öncelikle yıllık ortalama sıcaklık ve yıllık ortalama yağış değerleri girilmiştir. Ardından öncelikle her bir istasyon noktası için sıcaklık indis değerleri ve ayrı ayrı potansiyel evapotranspirasyon değeri formüller yardımıyla tespit edilerek, tablolardaki ilgili alana yazılmıștır.

Potansiyel evapotranspirasyon değerinden sonra gerçek evapotranspirasyon değeri, zemin rezervi, zemin rezerv değişimi, yıllık su fazlası, yıllık su noksanı, akış ve nemlilik gibi Thornthwaite iklim sınıflaması için gerekli tüm değerler sorgulamalar aracılığıyla tespit edilmiştir. Bu aşamada gerçek evapotranspirasyon tespiti için sorgulamalar yapılmış ve excel ortamında yazılan kodlamalar ile birlikte hesaplanmıştır.

İlk sorgulama herhangi bir ayın yağıș miktarının (P), potansiyel evapotranspirasyondan (ETP) fazla olması durumudur. İkinci sorgulama ise herhangi bir ayın yağış miktarının (P), potansiyel evapotranspirasyondan (ETP) az olması durumudur (Thornthwaite, 1948, MGM, 2017). İstasyon noktalarına dair hesaplanan potansiyel ETP ile yağış miktarı kıyaslanır ve iki sorgulamadan birisi seçilerek hesaplamalar yapılır. $\mathrm{Su}$ bilançosu tablosunun oluşturulmasındaki hesaplamalarda genel olarak zemin rezervinin artmaya başladığ aylar dikkate alınır. Ekim ayı ya da Ocak ayı zemin rezervinin artış gösterdiği aylar olduğundan, hesaplama yapılırken herhangi birinden itibaren su bilançosu hesaplarına başlanabilmektedir (Thornthwaite, 1948, MGM, 2017). Bu çalışma için zemin rezervi başlangıcı olarak Ocak ayı alınmıştır ve tüm hesaplamalara bu şekilde devam edilmiştir.

Tüm hesaplamalar sonucunda tüm illeri yansitan meteorolojik istasyon verilerinin su bilanço tabloları oluşturularak gerekli bilgiler temin edilmiştir. Artvin, Rize, Trabzon, Giresun, Ordu, Samsun illeri ile Trabzon-Akçaabat İlçesi, SamsunBafra İlçesi, Giresun-Şebinkarahisar İlçesi, ArtvinHopa İlçesi, Rize-Pazar İlçesi, Ordu-Ünye İlçesine ait su bilançoları hesaplanarak, her bir istasyon noktası için ayrı ayrı olmak üzere toplamda 12 adet tablo oluşturulmuştur. Bu makalede örnek olarak bu tablolardan Artvin İli ve Trabzon Akçaabat İlçesi için oluşturulan su bilanço tabloları örnek olarak sunulmuştur (Tablo 6a ve 6b).

Tablo 6a. Artvin ili su bilanço tablosu

ARTVIN İLI SU BİLANÇO TABLOSU

\begin{tabular}{llllllllllllll}
\hline AYLAR & $\mathbf{1}$ & $\mathbf{2}$ & $\mathbf{3}$ & $\mathbf{4}$ & $\mathbf{5}$ & $\mathbf{6}$ & $\mathbf{7}$ & $\mathbf{8}$ & $\mathbf{9}$ & $\mathbf{1 0}$ & $\mathbf{1 1}$ & $\mathbf{1 2}$ & YILLIK \\
\hline Sıcaklık & 2.4 & 3.7 & 7.1 & 11.8 & 15.7 & 18.8 & 21.1 & 21.6 & 18.5 & 14.3 & 8.5 & 4.1 & 12.29 \\
\hline Sicaklık indisi & 0.4 & 0.7 & 1.7 & 3.7 & 5.6 & 7.4 & 8.8 & 9.2 & 7.2 & 4.9 & 2.3 & 0.8 & 52.84 \\
\hline G & 0.8 & 0.8 & 1.0 & 1.1 & 1.3 & 1.3 & 1.3 & 1.2 & 1.0 & 1.0 & 0.8 & 0.8 & \\
\hline Potansiyel ETP & 4.5 & 8.0 & 23.5 & 51.1 & 87.9 & 111.7 & 129.7 & 123.5 & 83.7 & 59.6 & 24.1 & 9.2 & 716.49 \\
\hline Gerçek ETP & 4.5 & 8.0 & 23.5 & 51.1 & 87.9 & 119.6 & 36.0 & 33.6 & 39.7 & 59.6 & 24.1 & 9.2 & 496.67 \\
\hline Yağış & 99.9 & 70.0 & 66.9 & 52.7 & 55.5 & 52.0 & 36.0 & 33.6 & 39.7 & 69.5 & 86.7 & 87.8 & 750.09 \\
\hline Zemin rezervi & 100.0 & 100.0 & 100.0 & 100.0 & 67.6 & 0.0 & 0.0 & 0.0 & 0.0 & 9.9 & 72.4 & 151.0 & \\
\hline Zemin rezerv değișimi i & 0.0 & 0.0 & 0.0 & 0.0 & -32.4 & -67.6 & 0.0 & 0.0 & 0.0 & 9.9 & 62.5 & 78.6 & \\
\hline Su fazlası & 95.4 & 62.0 & 43.4 & 1.6 & 0.0 & 0.0 & 0.0 & 0.0 & 0.0 & 0.0 & 0.0 & 0.0 & 202.44 \\
\hline Su eksiği & 0.0 & 0.0 & 0.0 & 0.0 & 0.0 & 7.9 & 93.8 & 90.0 & 44.0 & 0.0 & 0.0 & 0.0 & 235.69 \\
\hline Akış & 47.7 & 54.9 & 37.2 & 11.7 & 0.4 & 0.0 & 0.0 & 0.0 & 0.0 & 0.0 & 0.0 & 0.0 & 151.83 \\
\hline Nemlilik & 21.1 & 7.8 & 1.8 & 0.0 & -0.4 & -0.5 & -0.7 & -0.7 & -0.5 & 0.2 & 2.6 & 8.5 & 4.7
\end{tabular}

Tablo 6b. Trabzon-Akçaabat ilçesi su bilanço tablosu

\begin{tabular}{llllllllllllll}
\multicolumn{10}{c}{ AKÇAABAT ILÇESI SU BILANÇO TABLOSU } \\
\hline AYLAR & $\mathbf{1}$ & $\mathbf{2}$ & $\mathbf{3}$ & $\mathbf{4}$ & $\mathbf{5}$ & $\mathbf{6}$ & $\mathbf{7}$ & $\mathbf{8}$ & $\mathbf{9}$ & $\mathbf{1 0}$ & $\mathbf{1 1}$ & $\mathbf{1 2}$ & YILLIK \\
\hline Sıcaklık & 7.0 & 7.0 & 8.5 & 11.4 & 15.9 & 20.6 & 23.7 & 24.3 & 20.8 & 16.9 & 12.1 & 8.9 & 14.8 \\
\hline Sıcaklık indisi & 1.5 & 1.6 & 2.2 & 3.5 & 5.7 & 8.5 & 10.1 & 10.6 & 8.3 & 6.1 & 3.7 & 2.4 & 64.2 \\
\hline G & 0.8 & 0.8 & 1.0 & 1.1 & 1.3 & 1.3 & 1.3 & 1.2 & 1.0 & 1.0 & 0.8 & 0.8 & \\
\hline Potansiyel ETP & 14.7 & 14.6 & 24.3 & 41.7 & 80.9 & 119.8 & 147.8 & 142.2 & 93.4 & 68.3 & 33.4 & 21.1 & 802.3 \\
\hline Gerçek ETP & 14.7 & 14.6 & 24.3 & 41.7 & 80.9 & 177.3 & 25.6 & 35.4 & 67.3 & 68.3 & 33.4 & 21.1 & 604.7 \\
\hline Yağıș & 78.7 & 66.0 & 54.6 & 48.7 & 43.7 & 40.1 & 25.6 & 35.4 & 67.3 & 107.1 & 89.6 & 76.1 & 732.8 \\
\hline Zemin rezervi & 100.0 & 100.0 & 100.0 & 100.0 & 137.2 & 0.0 & 0.0 & 0.0 & 0.0 & 38.8 & 95.0 & 150.0 \\
\hline $\begin{array}{l}\text { Zemin rezerv } \\
\text { değişimi }\end{array}$ & 0.0 & 0.0 & 0.0 & 0.0 & -37.2 & -137.2 & 0.0 & 0.0 & 0.0 & 38.8 & 56.2 & 55.0 & \\
\hline Su fazlası & 63.9 & 51.4 & 30.3 & 6.9 & 0.0 & 0.0 & 0.0 & 0.0 & 0.0 & 0.0 & 0.0 & 0.0 & 152.5 \\
\hline Su eksiği & 0.0 & 0.0 & 0.0 & 0.0 & 0.0 & 57.5 & 122.2 & 106.8 & 26.2 & 0.0 & 0.0 & 0.0 & 312.6 \\
\hline Akış & 32.0 & 41.7 & 28.0 & 11.0 & 1.7 & 0.0 & 0.0 & 0.0 & 0.0 & 0.0 & 0.0 & 0.0 & 114.4 \\
\hline Nemlilik & 4.3 & 3.5 & 1.2 & 0.2 & -0.5 & -0.7 & -0.8 & -0.8 & -0.3 & 0.6 & 1.7 & 2.6 & -8.7 \\
\hline
\end{tabular}




\subsection{Thornthwaite yağış etkinlik indeksinin hesaplanması}

$\mathrm{Bu}$ aşamada, oluşturulan su bilançosu tablosu ile elde edilen yıllık su noksanı, yıllık su fazlası ve yllık potansiyel evapotranspirasyon değerleri kullanılarak her bir istasyon için yağış etkinlik indeksi hesaplanmıștır. Buna bağlı olarak yağış etkinlik indeksi hesabına karşlık gelen iklim özelliği belirlenmiştir. Yağış etkinlik indeksi formülü kullanılarak elde edilen değer Thornthwaite sınıflandırmasındaki iklim tiplerinin birinci harfini yansıtacak şekilde tanımlanmıştır ve meteorolojik istasyon noktalarının iklim özellikleri belirlenmiștir (Tablo 7).

Ardından tüm bölgeyi yansıtacak iklim haritasının üretilmesi için, elde edilen sonuç değerler ArcGIS 10.6 yazılıminda Kriging Enterpolasyon yöntemi uygulanarak analiz edilmiş ve sonuçlar iklim sınır haritasının ilk harfini yansıtacak yağış etkinlik indeksi haritaları ile sunulmuştur ( Şekil 3).

Tablo 7. Karadeniz Bölgesi meteorolojik istasyon noktalarının Thornthwaite yağış etkinlik indeksi (lm) değeri ve iklim özellikleri

\begin{tabular}{|c|c|c|c|c|c|c|c|}
\hline $\begin{array}{l}\text { ISTASYON } \\
\text { ADI }\end{array}$ & $\begin{array}{c}\mathrm{Y} \\
\text { (ENLEM) }\end{array}$ & $\begin{array}{c}\mathrm{X} \\
\text { (BOYLAM) }\end{array}$ & YİLSUFAZL & YİLSUEKS & YİLETP & $\operatorname{lm}$ & $\begin{array}{c}\text { İKLİM } \\
\text { ÖZELLİĞİ }\end{array}$ \\
\hline Akçaabat & 41.0325 & 39.5615 & 152.5 & 312.6 & 604.7 & -5.8 & $\mathrm{C} 1$ \\
\hline Artvin & 41.1752 & 41.8187 & 202.4 & 235.7 & 496.7 & 12.3 & $\mathrm{C} 2$ \\
\hline Bafra & 41.5515 & 35.9247 & 152.9 & 290.1 & 596.8 & -3.5 & $\mathrm{C} 1$ \\
\hline Giresun & 40.9227 & 38.3878 & 290.1 & 55.1 & 733.0 & 35.1 & B1 \\
\hline Hopa & 41.4065 & 41.433 & 1577.3 & 0.0 & 792.2 & $\begin{array}{c}199 . \\
1\end{array}$ & $\mathrm{~A}$ \\
\hline Ordu & 40.9838 & 37.8858 & 243.9 & 211.0 & 654.4 & 17.9 & $\mathrm{C} 2$ \\
\hline Rize Pazar & 41.1777 & 40.8993 & 1409.2 & 0.0 & 754.7 & $\begin{array}{c}186 . \\
7\end{array}$ & $\mathrm{~A}$ \\
\hline Rize & 41.04 & 40.5013 & 1528.5 & 0.0 & 797.6 & $\begin{array}{c}191 . \\
6\end{array}$ & A \\
\hline Samsun & 41.3435 & 36.3878 & 147.3 & 300.1 & 606.0 & -5.4 & $\mathrm{C} 1$ \\
\hline Şebinkarahisar & 40.2872 & 38.4193 & 155.8 & 368.1 & 491.6 & -13.2 & C1 \\
\hline Trabzon & 40.9985 & 39.7649 & 171.9 & 276.7 & 643.6 & 12.3 & $\mathrm{C} 2$ \\
\hline Ünye & 41.143 & 37.293 & 280.7 & 174.9 & 736.4 & 23.9 & B1 \\
\hline
\end{tabular}

(YILSUFAZL: Yıllık su fazlası, YILLSUEKS: Yllık su eksiği, YíLETP: Yıllık ETP değeri)

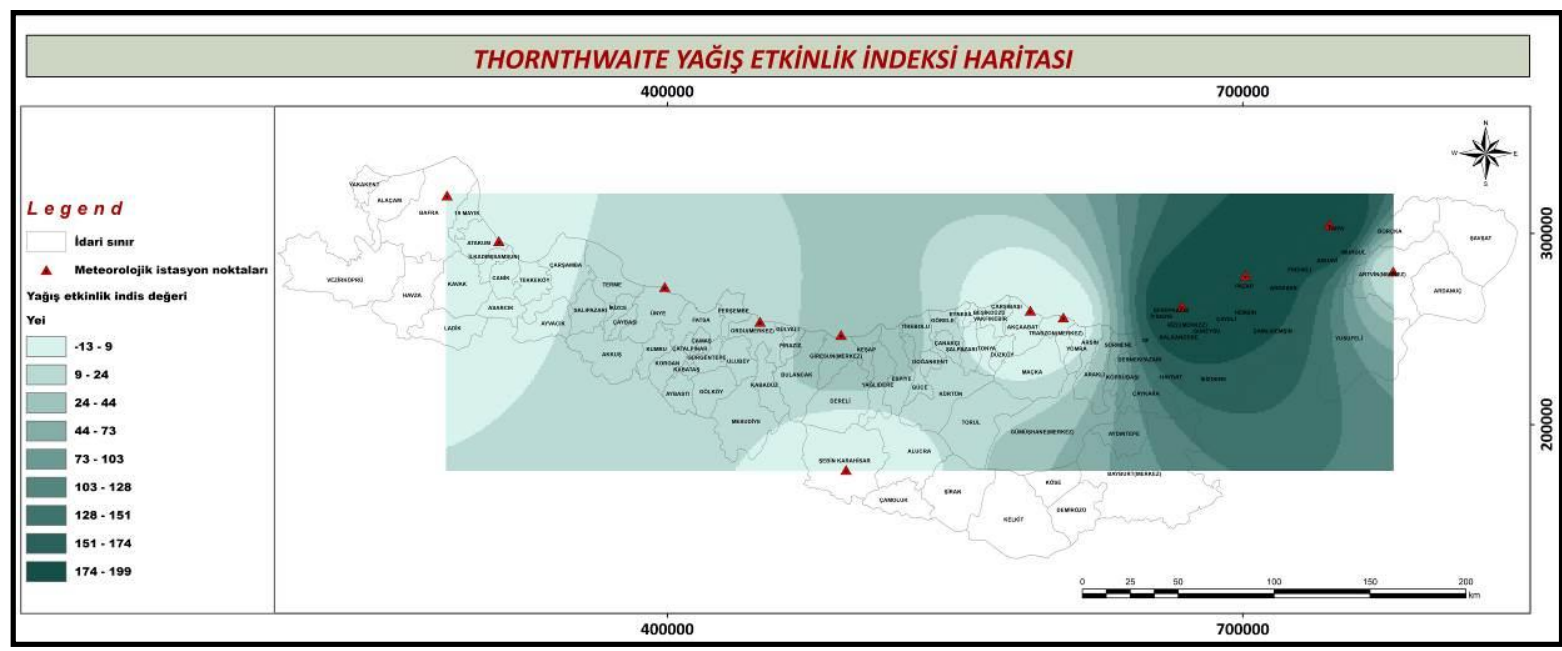

Şekil 3. Kriging yöntemi ile tespit edilmiş Karadeniz Bölgesi Thornthwaite yağış etkinlik indeksi haritası

\subsection{Thornthwaite sıcaklık etkinlik indeksinin hesap edilmesi}

$\mathrm{Bu}$ aşamada, Thornthwaite sıcaklık etkinlik indeksi hesabı yapılmıştır. Yöntemde belirtilen formüller kullanılarak her bir istasyon için yıllık ETP değerleri kıyaslanmış ve sıcaklık etkinlik indeksi tespit edilmiştir. Böylece sıcaklık etkinlik indeksine karşıllk gelen iklim özelliği belirlenmiștir. Sıcaklık etkinlik indeksi kıyaslanarak elde edilen değer Thornthwaite sinıflandırmasındaki iklim tiplerinin ikinci harfini yansıtacak şekilde tanımlanmıştır ve meteorolojik istasyon noktalarının iklim özellikleri belirlenmiştir (Tablo 8).

Ardından tüm bölgeyi yansıtacak iklim sınıflandırma haritasının üretilmesi için yine iklim özelliği belirlenmiș istasyon verileri kullanılarak ArcGIS 10.6 yazilıminda Kriging Enterpolasyon yöntemi uygulanarak analiz edilmiş ve sonuçlar iklim sınır haritasının ikinci harfini yansıtacak sıcaklık etkinlik indeks haritaları ile sunulmuştur (Şekil 4). 
Tablo 8. Karadeniz Bölgesi meteorolojik istasyon noktalarının Thornthwaite sıcaklık etkinlik indeksi değeri ve iklim özellikleri

\begin{tabular}{|c|c|c|c|c|}
\hline ISTASYON ADI & Y(ENLEM) & X (BOYLAM) & YILLIK ETP & İKLİM ÖZELLİĞİ \\
\hline Akçaabat & 41.0325 & 39.5615 & 604.7 & B'1 \\
\hline Artvin & 41.1752 & 41.8187 & 496.7 & $C^{\prime} 2$ \\
\hline Bafra & 41.5515 & 35.9247 & 596.8 & $B^{\prime} 1$ \\
\hline Giresun & 40.9227 & 38.3878 & 733.0 & $B^{\prime} 2$ \\
\hline Hopa & 41.4065 & 41.433 & 792.2 & $B^{\prime} 2$ \\
\hline Ordu & 40.9838 & 37.8858 & 654.4 & $B^{\prime} 1$ \\
\hline Rize Pazar & 41.1777 & 40.8993 & 754.7 & B'2 \\
\hline Rize & 41.04 & 40.5013 & 797.6 & B'2 \\
\hline Samsun & 41.3435 & 36.3878 & 606.0 & $B^{\prime} 1$ \\
\hline Şebinkarahisar & 40.2872 & 38.4193 & 491.6 & $\mathrm{C}^{\prime} 2$ \\
\hline Trabzon & 40.9985 & 39.7649 & 643.6 & $B^{\prime} 1$ \\
\hline Ünye & 41.143 & 37.293 & 736.4 & $B^{\prime} 2$ \\
\hline
\end{tabular}

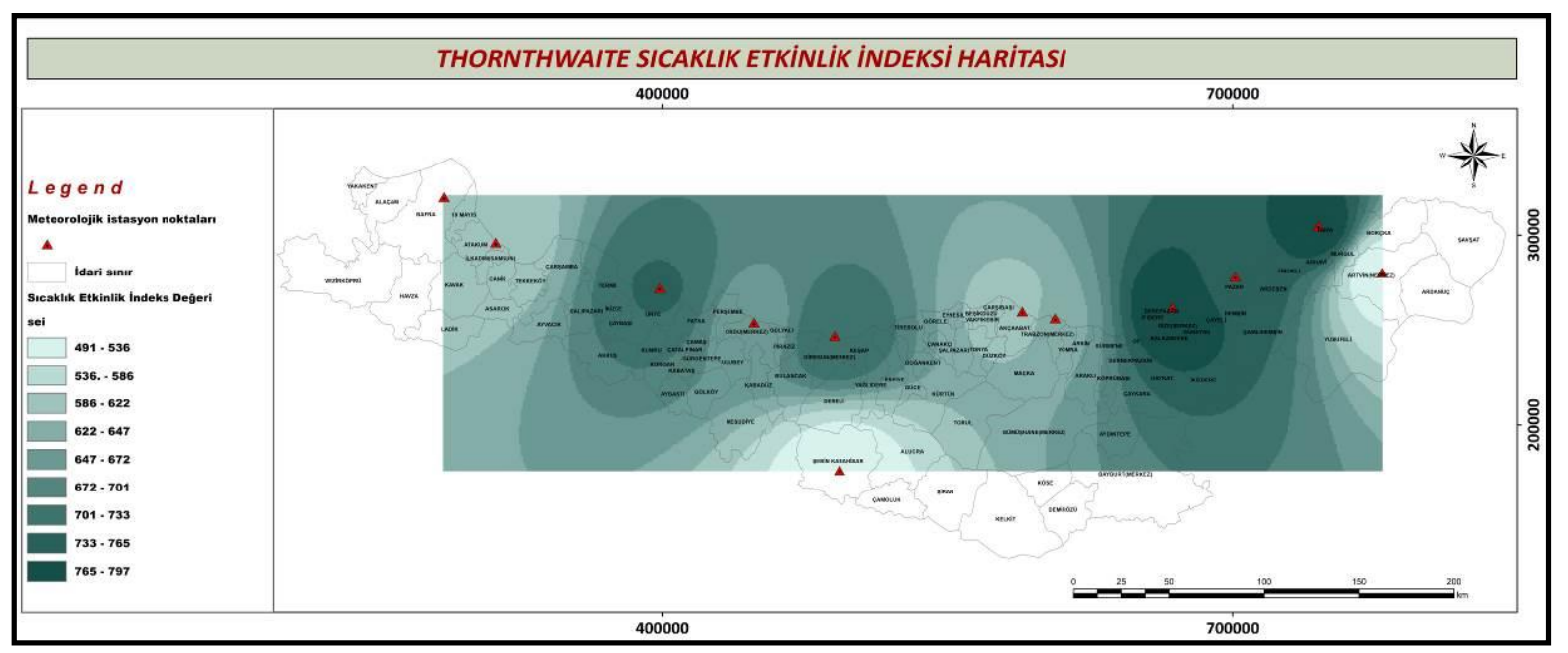

Şekil 4. Kriging yöntemi ile tespit edilmiş Karadeniz Bölgesi Thornthwaite sıcaklık etkinlik indeksi haritası

\subsection{Thornthwaite yağış rejimi indekslerinin hesap edilmesi}

Çalışmanın bu aşamasında yağıșın mevsimlere bağlı olarak değişen tipleri tespit edilmiştir. Bunun için su bilançolarında hazırlanmış yıllık ETP değeri, su fazlası ve su noksanı değerleri kullanılarak ilgili formüller yardımıyla hesaplamalar yapılmıştır. Meteorolojik istasyonların tümü yağışlı iklimlere denk geldiğinden bu çalışmada nemli alanlar için kuraklık indeksi değerleri hesaplanmıştır (Tablo 9). Sonuçta bulunan değerler ile meteorolojik istasyonların nemlilik indeksine karşılık gelen değerler Thornthwaite sınıflandırmasındaki iklim özelliğinin üçüncü harfini yansıtacak şekilde tanımlanmıştır.

Ardından tüm bölgeyi yansıtacak iklim sınıflandırma haritasının üretilmesi için yine iklim özelliği belirlenmiş istasyon verileri kullanılarak ArcGIS 10.6 yazılımında Kriging enterpolasyon yöntemi uygulanarak analiz edilmiş ve sonuçlar iklim sınır haritasının üçüncü harfini yansıtacak kuraklık indeks haritaları ile sunulmuştur (Şekil 5).

Tablo 9. Karadeniz Bölgesi meteorolojik istasyon noktalarının Thornthwaite kuraklık indeksi değeri ve iklim özelliği

\begin{tabular}{lcccccc}
\hline İSTASYON ADI & Y(ENLEM) & X(BOYLAM) & YILSUEKS & YILETP & la & \multicolumn{1}{c}{ ÍKLIM ÖZELLIĞ́̇ } \\
\hline Akçaabat & 41.0325 & 39.5615 & 312.6 & 604.7 & 51.7 & $\mathrm{~s} 2$ \\
\hline Artvin & 41.1752 & 41.8187 & 235.7 & 496.7 & 47.5 & $\mathrm{~s} 2$ \\
\hline Bafra & 41.5515 & 35.9247 & 290.1 & 596.8 & 48.6 & $\mathrm{~s} 2$ \\
\hline Giresun & 40.9227 & 38.3878 & 55.1 & 733.0 & 7.5 & $\mathrm{r}$ \\
\hline Hopa & 41.4065 & 41.433 & 0.0 & 792.2 & 0.0 & $\mathrm{r}$ \\
\hline Ordu & 40.9838 & 37.8858 & 211.0 & 654.4 & 32.2 & $\mathrm{~s}$ \\
\hline Rize Pazar & 41.1777 & 40.8993 & 0.0 & 754.7 & 0.0 & $\mathrm{r}$ \\
\hline Rize & 41.04 & 40.5013 & 0.0 & 797.6 & 0.0 & $\mathrm{r}$ \\
\hline Samsun & 41.3435 & 36.3878 & 300.1 & 606.0 & 49.5 & $\mathrm{~s} 2$ \\
\hline Șebinkarahisar & 40.2872 & 38.4193 & 368.1 & 491.6 & 74.9 & $\mathrm{~s} 2$ \\
\hline Trabzon & 40.9985 & 39.7649 & 276.7 & 643.6 & 43.0 & $\mathrm{~s} 2$ \\
\hline Ünye & 41.143 & 37.293 & 174.9 & 736.4 & 23.8 & $\mathrm{~s}$ \\
\hline
\end{tabular}




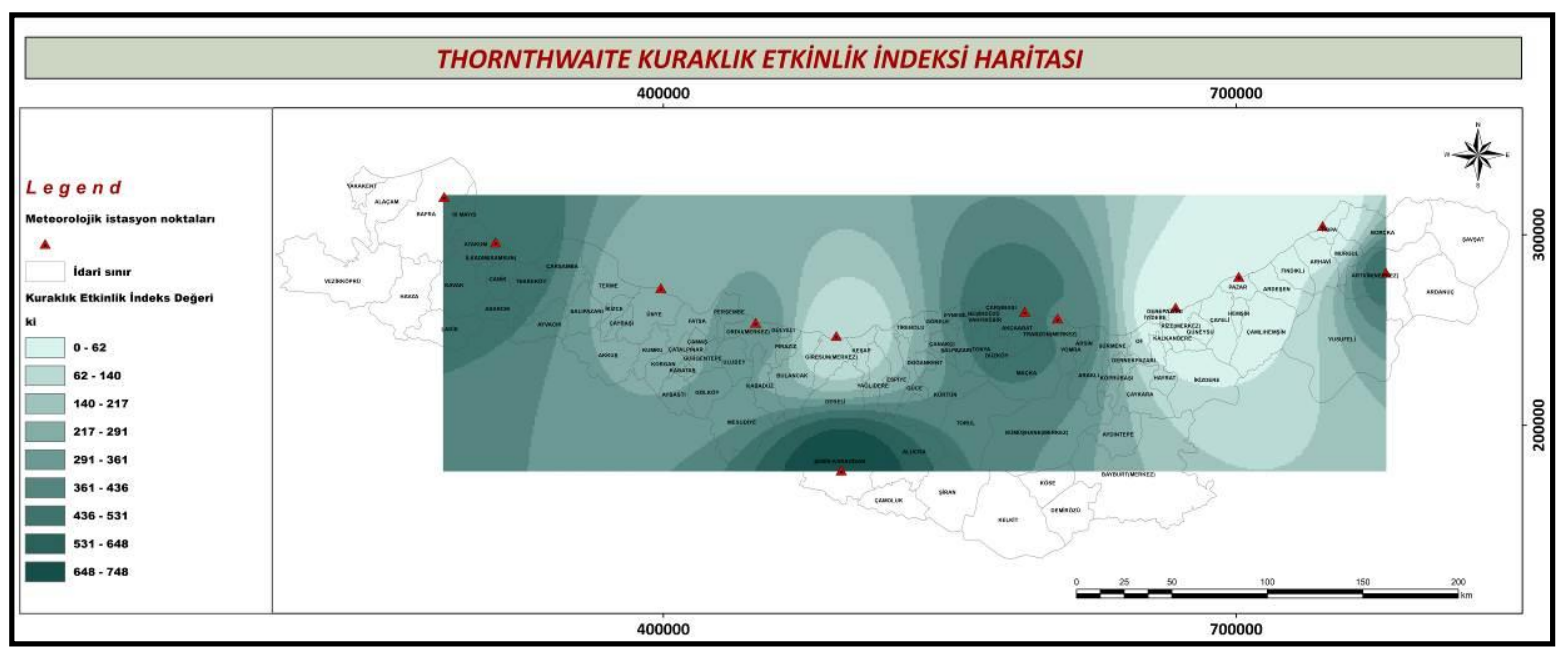

Şekil 5. Kriging yöntemi ile tespit edilmiş Karadeniz Bölgesi Thornthwaite kuraklık indeksi haritası

\subsection{Thornthwaite ETP'nin üç yaz oranına olan indeksinin hesap edilmesi}

Bu aşamada, Thornthwaite ETP'nin üç yaz oranına olan indeksi hesap edilmiştir. Burada üç yaz ayı olarak haziran, temmuz ve ağustos aylarındaki ETP değerlerinin oranları dikkate alınmıştır. Elde edilen değerler ile meteorolojik istasyon verilerinin iklim özellikleri belirlenmiş, sonuçlar Thornthwaite sınıflandırmasındaki iklim özelliğinin dördüncü harfini yansıtacak șekilde tanımlanmıştır (Tablo 10).

Ardından tüm bölgeyi yansıtacak iklim sınıflandırma haritasının üretilmesi için yine iklim tipi belirlenmiş istasyon verileri kullanılarak ArcGIS 10.6 yazılımında Kriging enterpolasyon yöntemi uygulanarak analiz edilmiş ve sonuçlar iklim sınır haritasının dördüncü harfini yansıtacak haritalar ile sunulmuştur (Şekil 6).

Tablo 10. Karadeniz Bölgesi meteorolojik istasyon noktalarının Thornthwaite oran indisine göre (Denizellikkarasallık) tanımlamalar

\begin{tabular}{|c|c|c|c|c|c|c|}
\hline İSTASYON ADI & Y(ENLEM) & X(BOYLAM) & YILLIK ETP & ÜÇ YAZ AYI & ORANI & HARF \\
\hline Akçaabat & 41.0325 & 39.5615 & 604.7 & 300.08 & 39.4 & $a^{\prime}$ \\
\hline Artvin & 41.1752 & 41.8187 & 496.7 & 314.74 & 38.1 & $a^{\prime}$ \\
\hline Bafra & 41.5515 & 35.9247 & 596.8 & 315.77 & 42.3 & $a^{\prime}$ \\
\hline Giresun & 40.9227 & 38.3878 & 733.0 & 304.75 & 47.7 & $\mathrm{a}^{\prime}$ \\
\hline Hopa & 41.4065 & 41.433 & 792.2 & 317.08 & 50.6 & $b^{\prime} 4$ \\
\hline Ordu & 40.9838 & 37.8858 & 654.4 & 316.08 & 42.7 & $\mathrm{a}^{\prime}$ \\
\hline Rize Pazar & 41.1777 & 40.8993 & 754.7 & 312.47 & 50.3 & $b^{\prime} 4$ \\
\hline Rize & 41.04 & 40.5013 & 797.6 & 314.12 & 51.5 & $b^{\prime} 4$ \\
\hline Samsun & 41.3435 & 36.3878 & 606.0 & 310.90 & 43.2 & $a^{\prime}$ \\
\hline Şebinkarahisar & 40.2872 & 38.4193 & 491.6 & 310.52 & 35.9 & $a^{\prime}$ \\
\hline Trabzon & 40.9985 & 39.7649 & 643.6 & 317.08 & 40.2 & $a^{\prime}$ \\
\hline Ünye & 41.143 & 37.293 & 736.4 & 343.97 & 47.9 & $a^{\prime}$ \\
\hline
\end{tabular}

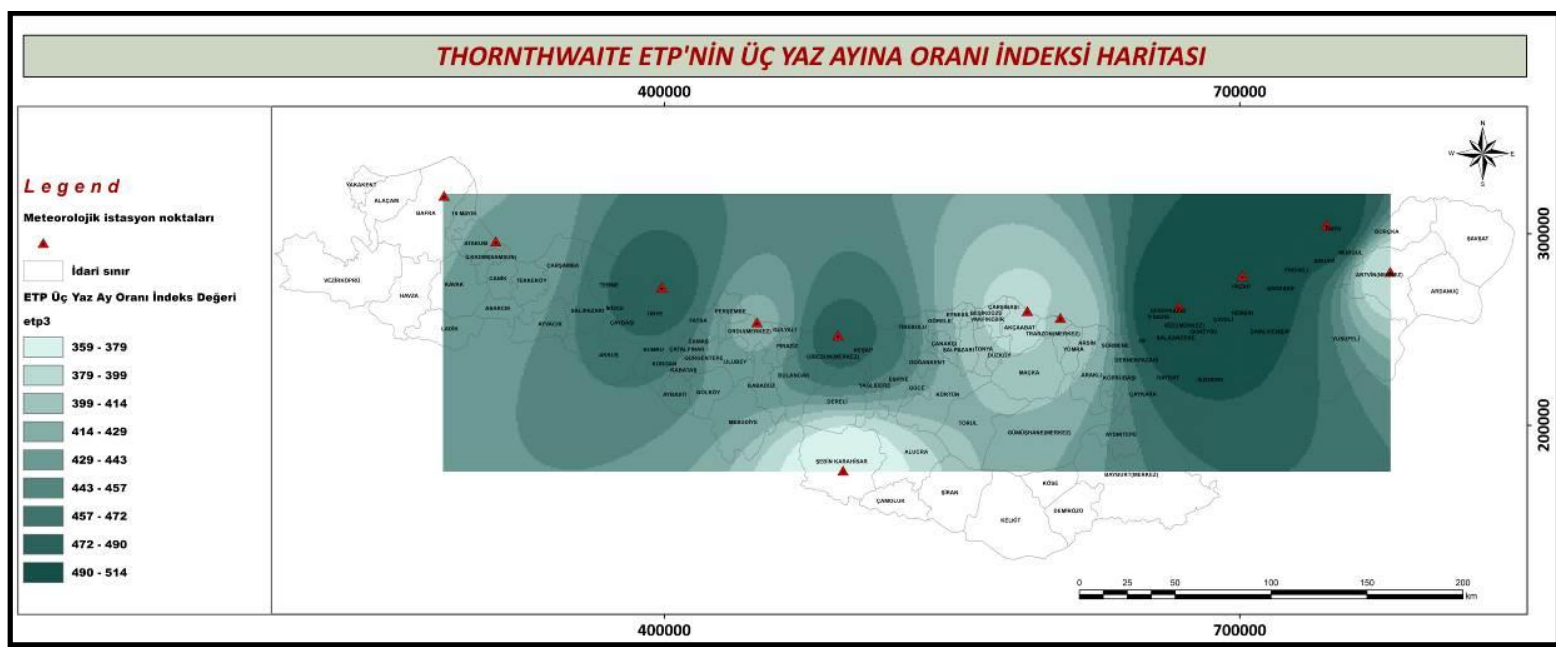

Şekil 6. Kriging yöntemi ile tespit edilmiş Karadeniz Bölgesi Thornthwaite ETP’nin üç yaz ayına oranı indeksi haritası 


\subsection{Doğu Karadeniz Bölgesi'nin Thornthwaite İklim Sınıflama Yöntemine Göre İklim Sınıflarının Belirlenmesi}

Çalışmanın son aşamasında tüm uygulama adımlarından elde edilen sonuç değerler, kullanılan istasyon noktaları bazında bütünleștirilmiştir. İklim sınıflandırması tespiti için gerçekleștirilen yağış etkinlik indeksi, sıcaklık etkinlik indeksi, yağış rejim indeksi ve ETP'nin üç yaz oranına olan indeksi hesabı tüm analiz sonuçları birleștirilerek Doğu Karadeniz Bölgesi için seçilen pilot istasyonların iklim sınıfları Thornthwaite iklim sınıflama yöntemine göre tespit edilmiş ve tek bir tabloda özet bilgi şeklinde sunulmuştur (Tablo 11).

Tablo 11. Karadeniz Bölgesi meteorolojik istasyon noktalarının Thornthwaite iklim sınıflandırma yöntemine göre iklim indeks değerleri ve iklim özellikleri

\begin{tabular}{|c|c|c|c|c|c|c|c|}
\hline \multicolumn{4}{|c|}{ THORNTHWAİTE İKLİM İNDEKSLERİ } & \multicolumn{4}{|c|}{ THORNTHWAİTE İKLİM ÖZELLİKLERİ } \\
\hline Akçaabat & $\mathrm{C} 1$ & $\mathrm{~B}^{\prime} 1$ & s2 & $\begin{array}{l}\text { Kurak-Yarı } \\
\text { Nemli }\end{array}$ & $\begin{array}{l}\text { 1.Dereceden } \\
\text { Mezotermal }\end{array}$ & $\begin{array}{l}\text { Yazın Şiddetli } \\
\text { Su Noksanı }\end{array}$ & Tam Denizel \\
\hline Artvin & $\mathrm{C} 2$ & $\mathrm{C}^{\prime} 2$ & s2 & Yarı Nemli & $\begin{array}{l}\text { 2.Dereceden } \\
\text { Mikrotermal }\end{array}$ & $\begin{array}{l}\text { Yazın Şiddetli } \\
\text { Su Noksanı }\end{array}$ & Tam Denizel \\
\hline Bafra & $\mathrm{C} 1$ & $\mathrm{~B}^{\prime} 1$ & s2 & $\begin{array}{l}\text { Kurak-Yarı } \\
\text { Nemli }\end{array}$ & $\begin{array}{l}\text { 1.Dereceden } \\
\text { Mezotermal }\end{array}$ & $\begin{array}{l}\text { Yazın Şiddetli } \\
\text { Su Noksanı }\end{array}$ & Tam Denizel \\
\hline Giresun & B1 & $\mathrm{B}^{\prime} 2$ & $a^{\prime}$ & Nemli & $\begin{array}{l}\text { 2.Dereceden } \\
\text { Mezotermal }\end{array}$ & $\begin{array}{c}\text { Su Noksanı } \\
\text { Yok veya Az }\end{array}$ & Tam Denizel \\
\hline Hopa & $\mathrm{A}$ & $B^{\prime} 2$ & b'4 & Çok Nemli & $\begin{array}{l}\text { 2.Dereceden } \\
\text { Mezotermal }\end{array}$ & $\begin{array}{c}\text { Su Noksanı } \\
\text { Yok veya Az }\end{array}$ & Denizel \\
\hline Ordu & $\mathrm{C} 2$ & $\mathrm{~B}^{\prime} 1$ & $a^{\prime}$ & Yarı Nemli & $\begin{array}{l}\text { 2.Dereceden } \\
\text { Mezotermal }\end{array}$ & $\begin{array}{l}\text { Yazın Orta } \\
\text { Derecede Su } \\
\text { Noksanı }\end{array}$ & Tam Denizel \\
\hline Rize Pazar & $\mathrm{A}$ & $\mathrm{B}^{\prime} 2$ & b'4 & Çok Nemli & $\begin{array}{l}\text { 2.Dereceden } \\
\text { Mezotermal }\end{array}$ & $\begin{array}{l}\text { Su Noksanı } \\
\text { Yok veya Az }\end{array}$ & Denizel \\
\hline Rize & A & $\mathrm{B}^{\prime} 2$ & $b^{\prime} 4$ & Çok Nemli & $\begin{array}{l}\text { 2.Dereceden } \\
\text { Mezotermal }\end{array}$ & $\begin{array}{c}\text { Su Noksanı } \\
\text { Yok veya Az }\end{array}$ & Denizel \\
\hline Samsun & C1 & B'1 $^{\prime}$ & $a^{\prime}$ & $\begin{array}{l}\text { Kurak-Yarı } \\
\text { Nemli }\end{array}$ & $\begin{array}{l}\text { 1.Dereceden } \\
\text { Mezotermal }\end{array}$ & $\begin{array}{l}\text { Yazın Şiddetli } \\
\text { Su Noksanı }\end{array}$ & Tam Denizel \\
\hline $\begin{array}{l}\text { Şebinkarahis } \\
\text { ar }\end{array}$ & $\mathrm{C} 1$ & $C^{\prime} 2$ & $a^{\prime}$ & $\begin{array}{l}\text { Kurak-Yarı } \\
\text { Nemli }\end{array}$ & $\begin{array}{l}\text { 2.Dereceden } \\
\text { Mikrotermal }\end{array}$ & $\begin{array}{l}\text { Yazın Şiddetli } \\
\text { Su Noksanı }\end{array}$ & Tam Denizel \\
\hline Trabzon & $\mathrm{C} 2$ & $\mathrm{~B}^{\prime} 1$ & s2 & Yarı Nemli & $\begin{array}{l}\text { 1.Dereceden } \\
\text { Mezotermal }\end{array}$ & $\begin{array}{l}\text { Yazın Şiddetli } \\
\text { Su Noksanı }\end{array}$ & Tam Denizel \\
\hline Ünye & B1 & $\mathrm{B}^{\prime} 2$ & $\mathrm{a}^{\prime}$ & Nemli & $\begin{array}{l}\text { 2.Dereceden } \\
\text { Mezotermal }\end{array}$ & $\begin{array}{c}\text { Yazın Orta } \\
\text { Derecede Su } \\
\text { Noksanı }\end{array}$ & Tam Denizel \\
\hline
\end{tabular}

\section{SONUÇLAR ve TARTIŞMA}

$\mathrm{Bu}$ çalışmada Artvin, Ordu, Rize, Rize-Pazar, Trabzon, Şebinkarahisar, Akçaabat, Ünye, Bafra, Hopa, Giresun ve Samsun'da yer alan meteorolojik istasyon noktalarını kapsayan Karadeniz Bölgesi için Ulusal İklim Değiş̧ikliği Stratejisinin amaçlarına ve FIG'in iklimden kaynaklı sorunlarına cevap verecek yönde, iklim sınırlarının tespiti gerçekleștirilmiştir. $\mathrm{Bu}$ amaçla iklim sınıflandırma yöntemlerinden Thornthwaite iklim sinıflaması yöntemi kullanılmıştır. Öncelikle Karadeniz Bölgesinde seçilen meteorolojik istasyon noktalarının son 30 yılllk dönemine (1988-2018) denk gelen ölçüm verileri temin edilmiș; elde edilen veriler konumla ilișkilendirilmiş ve Thornthwaite iklim sınıflama yöntemi kullanılarak her bir istasyonun iklim tipi tespit edilmiştir. Meteorolojik istasyon noktalarının iklim tipi sonuçlarına bakıldığında bölgenin özellikle çok fazla yağış alan kısımları yani Rize, Pazar ve Hopa'da iklim tipinin çok nemli olduğu; diğer istasyon noktalarının ise yarı nemli, nemli, kurakyarı nemli şeklinde iklim tipine sahip olduğu tespit edilmiștir. Yine Thornthwaite iklim özelliklerine bakıldığında bölgedeki iller $1 . \quad$ Dereceden Mezotermal, 2. Dereceden Mezotermal ve 2. Dereceden Mikrotermal özelliklere sahip iklim türlerine denk geldiği belirlenmiștir. Ayrıca iklim özelliği olarak çok fazla yağış alan bölgelerde su noksanı neredeyse hiç yok ya da az miktarda, diğere istasyon noktalarında ise su noksanının yaz aylarında orta ya da şiddetli olduğu tespit edilmiştir. Son olarak istasyon noktalarının tam denizel ve denizel özellikte iklim özelliklerine sahip oldukları da görülmüştür.

Meteorolojik istasyon noktalarının iklim tipleri belirlendikten sonra, bu istasyon noktalarının sonuç değerleri kullanılarak Kriging enterpolasyon yöntemi ile bir analiz daha gerçekleștirilmiștir ve tüm bölgeyi temsil edecek șekilde ara noktalarında iklim tiplerini yansıtan iklim sınır haritaları elde edilmiştir. Böylece meteorolojik istasyon noktaları dışında kalan bölgelere iklim tahmini gerçekleștirilmiştir. İklim özelliklerinin ilçe ya da il bazlı olarak değerlendirilmesinin dışında bu çalışmada raster tabanlı haritalar üretildiğinden konumsal anlamda iklim sınırlarının daha doğru bir şekilde tanımlanması hedeflenmiștir. 
Daha önceden MGM tarafından gerçekleştirilen Thornthwaite iklim sınıflama çalışması incelendiğinde (MGM, 2017) bu çalıșmada elde edilen sonuçların farklılık gösterdiği tespit edilmiştir. Bunun sebebi MGM'nin bu analizleri 2010 yllına kadar gerçekleștirmesi ve 2010 yllından 2018 yılına kadarki süreçte ülkemizde iklimin her geçen gün daha da farklılașmasından ileri geldiği düşünülmektedir. Ayrıca MGM'nin yaptığı çalışmada iklim tipleri ilçe sınırlarına dayandırılarak sunulmuştur; oysaki ilçe yüzölçümlerine bağlı olarak tamamında aynı iklim tipi görülmeyebilir. Bu sebeple bu çalışmada MGM'nin gerçekleştirmiş olduğu çalımadan farklı olarak istasyon noktaları esas alınarak, aradaki diğer noktalara konumsal tahmin yapılarak iklim sınıfı sınırları idari sınırlardan bağımsız olarak raster tabanlı grid ağı şeklinde tanımlanmış ve akabinde sınırlarla çakıştırılmıştır. Böylece aynı il ya da ilçe sınırları içerisine düşen farklı iklim tipleri var ise belirlenebilmiştir.

Elde edilen sonuçlar, özellikle iklimin değiştiği bölgeleri mümkün olduğunca tanımlayacağından iklime bağlı gerçekleştirilecek planlamalara yardımcı olacak niteliğe sahiptir. Ayrıca Karadeniz Bölgesi için iklim sınırlarının çizilmiş olması ile bu bölgelerde iklimle ilişkili olabilecek sonraki planlama çalışmalarına katkı sağlayacaktır. İklim sınırlarının tespiti ile birlikte iklimden kaynaklı mülkiyet ve arazi kullanımının değişikliğinin sebepleri irdelenebilecek, iklimden kaynaklı göç problemlerinin sorgulanabileceği ve önlem alınabileceği çalışmalara altlık olabilecek çözüm stratejileri geliştirilebilecektir. Ayrıca Ulusal İklim Değişikliği Stratejisinin ve FIG'in yayınladığı bildirgenin gereksinimlerine doğrultusunda ve mülkiyet kullanımının kısıtlanmasına yönelik tedbirlerin alınmasına, devlet politikalarının geliștirilmesine katkı sağlayacak bir çalışma olması hedeflenmiştir. İklim sınırlarının haritalandırılması yoluyla iklim değiş̧ikliklerinin zaman içerisinde izlenmesi; değişimin yönü ve hızının tespit edilmesine olanak sağlayacaktır. Bu bağlamda ulusal ve küresel ölçekte iklim değişikliğine yönelik politikalar geliştirilebilecektir.

\section{KAYNAKÇA}

Acheson E. S., Galanis, E., Bartlett, K. and Klinkenberg, B. (2019). Climate Classification System-Based Determination of Temperate Climate Detection of Cryptococcus gattii sensu lato. Emerg Infect Dis., 25(9): 1723-1726. doi: 10.3201/eid2509.181884.

Akar, A. (2017). Evaluation Of Accuracy Of Dems Obtained From Uav-Point Clouds For Different Topographical Areas, International Journal of Engineering and Geosciences, 2(3), 110-117.
Akın, H. S., Dalfez, H. N., Önol, B. ve Şen, L. (2011). Türkiye ve Bölgesinde İklimin Geleceğine Köppen-Geiger İklim Sınıflandırması Dayalı Bir Bakış. Paper presented at the Uluslararası Katılımlı Coğrafya Kongresi (70. Yll anısına), İstanbul.

Aparecido, L. E. D., Rolim, G. D., Richetti, J., de Souza, P. S. and Johann, J. A. (2016). Koppen, Thornthwaite and Camargo climate classifications for climatic zoning in the State of Parana, Brazil. Ciencia E Agrotecnologia, 40(4), 405-417.

Apaydin, H., Anli, A.S. and Ozturk, F. (2011) Evaluation of topograph-ical and geographical effects on some climatic parameters in theCentral Anatolia Region of Turkey. International Journal of Clima-tology, 31(9), 1264-1279.

Aydeniz, A. (1985). Toprak Amenajmanı. Ankara: Ankara Üniversitesi, Ziraat Fakültesi Yayınları No:928.

Bayramoğlu, E. (2013). Trabzon İlinde İklim Değişikliğinin Mevsimsel Bitki Su Tüketimine Etkisi: Penman-Monteith Yöntemi. Kastamonu Üni., Orman Fakültesi Dergisi, 13(2), 300-306.

Belda, M., Holtanova, E., Halenka, T. and Kalvova, J. (2014). Climate classification revisited: from Köppen to Trewartha. Clim Res, 59, 1-13.

Birdal, A. C., Korkmaz, E., Erșen, G., Türk, T. and Atun, R. (2018). Monitoring Climate Changes by Geographical Information Systems: A Case Study of Izmir City. Artvin Çoruh Üniversitesi, Doğ Afet Çev Derg, 4(1), 45-55, Doi: 10.21324/dacd.363694.

Birsoy, Y ve Ölgen, M. K. (1992). Thornthwaite yöntemi ile su bilançosunun ve iklim tipinin belirlenmesinde bilgisayar kullanımı. Ege Coğrafya Dergisi, 6(1), 153-178.

Chen, D. and Chen, H. W. (2013). Using the Köppen classification to quantify climate variation and change: An example for 1901-2010. Environmental Development, 6, 69-79.

Çiçek, İ. (1996). Thornthwaite Metoduna Göre Türkiye'de İklim Tipleri. Ankara Üniversitesi, Dil ve Tarih Coğrafya Fakültesi, Coğrafya Araștırmaları Dergisi, 12, 33-71.

Çolak, H. E. (2010). Coğrafi bilgi sistemleri ile Doğu Karadeniz bölgesindeki kanser vakalarının konumsal analizleri, Karadeniz Teknik Üniversitesi, Fen Bilimleri Enstitüsü, Doktora Tezi, Trabzon. 
Demircan, M. ve Sensoy, S. (2010). Climatological Applications in Turkey. Republic of Turkey Ministry of Environment and Forestry Turkish State Meteorological Service, May, Ankara.

De Martonne, E. (1942). Nouvelle carte mondial de l'indice d'aridité, Annales de Géographie, 241250.

Erinç, S. (1949). The climates of Turkey according to Thornthwaite's classifications, Annals of the Association of American Geographers, 39(1), 2646.

Feddema, J. J. (2013). A Revised Thornthwaite-Type Global Climate Classification. Physical Geography, 26(6), 442-466.

FIG (2014). Kadastro 2014 - Gelecekteki Kadastral Sistem için bir vizyon. https://www.fig.net/resources/publications/fi gpub/cadastre2014/translation/c2014turkish.pdf

Fovell, R. G. and Fovell, M. C. (1993). Climate zones of the Conterminous United States Defined Using Cluster Analysis. Journal of Climate, 6, 21032135.

IPCC. (2014) In: Core Writing Team, Pachauri, R.K. and Meyer, L.A.(Eds.)Climate Change 2014: Synthesis Report. Contribution ofWorking Groups I, II and III to the Fifth Assessment Report of theIntergovernmental Panel on Climate Change. Geneva: IPCC.151 pp.

Kafalı Yılmaz F. ve Yılmaz, Ö. (2013). Rize and Ardahan Cases in Respect of Thornthwaite Climate Classification. 3rd International Geography Symposium- GEOMED 2013, Symposium Proceedings, ISBN: 978-60562253-8-3.

Kaufmann J. and Steudler, D. (1998). Cadastre 2014 - a vision for a future cadastral system, FIG Publication, Rüdlingen and Bern, Switzerland, 38ss.

Khorrami, B., Gunduz, O., Patel, N., Ghouzlane, S. and Najar, M. (2016). Land Surface Temperature Anomalies In Response To Changes In Forest Cover, International Journal of Engineering and Geosciences, 4(3), 149-156.

Köppen, W. (1918). Klassifikation der Klimada nach Temperatur, Niederschlag und Jahresablauf (Classification of climates according to temperature, precipitation and seasonal cycle. Petermanns Geographische Mitteilungen, 64,193-203.
Köppen, W. and Geiger, R. (1954). Klima der erde (Climate of the earth). Wall Map 1:16 Mill. KlettPerthes, Gotha.

MGM (2016). Meteoroloji Genel Müdürlüğü Resmi internet sayfası, İklim Sinıflandırmaları,https://www.mgm.gov.tr/ikli $\mathrm{m} /$ iklim-siniflandirmalari.aspx, 24.06.2019.

MGM (2017). İklim Sinıflandırmaları, http://www.mgm.gov.tr/FILES/iklim/iklim_si niflandirmalari.pdf. Son Erişim 18.11.2018.

Nacef, L., Bachari, N.E.I., Bouda, A. and Boubnia, R. (2016). Variability and Decadal Evolution Of Temperature and Salınity In The Mediterranean Sea Surface, International Journal of Engineering and Geosciences, 1(1),24-33.

Rahimi, J., Khalili, A. and Butterbach-Bahl, K. (2019). Projected changes in modified Thornthwaite climate zones over Southwest Asia using a CMIP5 multi-model ensemble. International Journal of Climatology, 39:4575-4594.

Rolim, G. S., Lucas E. and Aparecido, O. (2016). Camargo, Köppen and Thornthwaite climate classification systems in defining climatical regions of the state of São Paulo, Brazil. International Journal of Climatology, 36, 636643.

Tayanç, M. and Toros, M. (1997). Urbanization effects on regional climate change in the case of four large cities in Turkey. Climatic Change, 35, 501-524.

Tayanç, M., Karaca, M. and Yenigün, O. (1997) Annual and seasonal air temperature trend paterns of climate change and urbanization effects in relation with air pollutants in Turkey. Journal of Geophysical Research 102 D2, 1909-1919.

Thornthwaite, C. W. (1948). An approach toward a rational classification. Geographical Review, 38(1), 55-94.

TiDS (2010). T. C. Çevre ve Şehircilik Bakanlığ Türkiye İklim Değişikliği Stratejisi 2010-2023.

Trewartha, G. T. (1968). An introduction to climate. New York: McGraw-Hill.

Uyan, M. (2019). Comparison Of Different Interpolation Techniques In Determining of Agricultural Soll Index On Land Consolıdation Projects, International Journal of Engineering and Geosciences, 4(1), 28-35.

Verep, B., Şahin, C., Çiloğlu, E. ve İmamoğlu, H. O. (2002). Uzungöl'ün İklimi ve Çevresel Sorunları 
Üzerine Bir Çalışma. Atatürk Üniv. Ziraat Fak. Derg., 33(4), 353-358.

Wang, M. and Overland, J. E. (2004). Detecting Arctic Climate Change Using Koppen Climate Classification. Climatic Change, 67(1), 43-62.

Yaprak, S. ve Arslan, E. (2008). Kriging Yöntemi ve Geoit Yüksekliklerinin Enterpolasyonu. Jeodezi, Jeoinformasyon ve Arazi Yönetimi Dergisi, 2008/1, 98.

Yılmaz, E. ve Çiçek, İ. (2016). Türkiye Thornthwaite iklim sinfflandırması. Journal of Human Sciences, 13(3), 3973-3994.
Yılmaz, E. ve Çiçek, İ. (2018). Türkiye'nin detaylandırılmış Köppen-Geiger iklim bölgeleri. Journal of Human Sciences, 15(1), 225-242. doi:10.14687/jhs.v15i1.5040.

Zeroual, A., Assani, A. A., Meddi, M. and Alkama, R. (2019). Assessment of climate change in Algeria from 1951 to 2098 using the Köppen-Geiger climate classification scheme. Climate Dynamics, 52(1-2), 227-243. 